\title{
DNA Extraction from a Single Seed for Marker-Assisted Selection in Squash
}

\author{
Isabella Martinez, Vincent N. Michael, Yuqing Fu, Swati Shrestha, Geoffrey Meru* \\ Horticultural Sciences Department and Tropical Research \& Education Center, University of Florida, Homestead, FL, USA \\ Email: *gmeru@ufl.edu
}

How to cite this paper: Martinez, I., Michael, V.N., Fu, Y.Q., Shrestha, S. and Meru, G. (2021) DNA Extraction from a Single Seed for Marker-Assisted Selection in Squash. American Journal of Plant Sciences, 12, 19121925.

https://doi.org/10.4236/ajps.2021.1212132

Received: November 4, 2021

Accepted: December 25, 2021

Published: December 28, 2021

Copyright $\odot 2021$ by author(s) and Scientific Research Publishing Inc. This work is licensed under the Creative Commons Attribution International License (CC BY 4.0).

http://creativecommons.org/licenses/by/4.0/

(c) $\underset{\mathrm{By}}{\mathrm{B}}$ Open Access

\begin{abstract}
Marker-assisted selection is an important tool in squash (Cucurbita species) breeding. A seed-based genotyping system would not only allow selection of desirable individuals prior to planting, but also reduce the cost associated with leaf-derived DNA genotyping, such as the need for greenhouse facilities and ultra-low-temperature storage freezers. A robust seed-based genotyping system requires a non-destructive sampling method and DNA of sufficient quantity and quality for marker-assisted selection. In the current study, six cultivars representing Cucurbita pepo (Black Beauty and Yellow Crookneck), C. moschata (Butterbush and Fairytale), and C. maxima (Buttercup and Big Max) were used to develop a suitable seed-based genotyping system for squash. Seed chips for DNA extraction were sampled by removing $1 / 3$ of the distal end, while the remnant seed-embryos were sowed to assess germination potential. Four extraction methods including two column-based commercial kits (CTAB and ENZA) and two detergent-based conventional methods (CTAB and SDS) were assessed for DNA quality and quantity. Utility of extracted DNA for downstream applications was tested by genotyping with SSR and SNP markers. There was no significant difference in germination percentage between whole and cut seeds across the six cultivars. The average DNA concentration across methods ranged from $11.6 \mathrm{ng} / \mu \mathrm{L}$ to $62.6 \mathrm{ng} / \mu \mathrm{l}$, while the DNA quality $\left(\mathrm{A}_{260 / 280}\right)$ ranged from 0.89 to 1.95 . Although DNA was obtained for all the extraction methods, only EZNA and Favorgen methods yielded DNA of sufficient quality for marker-assisted selection.
\end{abstract}

\section{Keywords}

Cucurbita, Genotyping, DNA Markers, SNP, SSR

\section{Introduction}

The three cultivated species of squash (Cucurbita pepo, C. moschata, C. max- 
ima) constitute a major horticultural crop in the U.S valued for flesh and seed consumption, as well as ornamental purposes [1] [2] [3]. Breeding for improved yield, fruit quality, resistance to pests and diseases and tolerance to abiotic stresses is an important goal for squash breeders worldwide [4]. However, conventional methods for selection are resource intensive, especially for quantitative traits with low heritability [5] [6]. Availability of next generation sequencing technologies has facilitated development of applied genomic tools for improvement of Cucurbita species, including reference genomes [7] [8], linkage maps [9] [10] and transcriptomes [11]. To-date, many quantitative trait loci (QTL) and molecular markers associated with economically important traits in Cucurbita have been identified [5] [7] [9] [12] [13] [14] [15]. These genomic resources are important for accelerated development of improved squash cultivars for growers through marker-assisted selection.

Genotyping systems for marker-assisted selection primarily rely on leaf-derived DNA that require significant resource investment, including greenhouse facilities for seed germination and ultra-low-temperature freezers for tissue storage [16] [17] [18]. On the other hand, marker-assisted selection based on seed-derived DNA is a suitable alternative that not only allows selection prior to planting, but also helps reduce the cost associated with acquisition of expensive storage and greenhouse facilities [16] [19]. Seed-based genotyping requires development of a non-destructive sampling protocol that allows reliable germination of remnant seed-embryo, as well as a nucleic acid extraction method that yields DNA of sufficient quality and quantity for marker-assisted selection [20] [21]. Seed-based genotyping systems have been developed and applied for many crops, including watermelon [21], maize [16], soybean [22], barley [19], wheat [20], sesame and rice [17]. In the current study, a non-destructive seed-based genotyping system was developed for squash and applied in marker-assisted selection.

\section{Material and Methods}

\subsection{Plant Materials, Germination, and Seed Size Determination}

Six squash cultivars representing C. pepo (Black Beauty and Yellow Crookneck), C. moschata (Butterbush and Fairytale), and C. maxima (Buttercup and Big Max) species were used in the experiment. Seed-chips for DNA extraction were obtained by cutting off $1 / 3$ portion of the distal-end (cotyledon) using a steel blade (Figure 1) as previously described for watermelon [21].

The remnant proximal-end portions of the seeds containing the embryo were germinated in cells $(5.98 \times 3.68 \times 4.69 \mathrm{~cm})$ filled with Proline C/B growing mix (Jolly Gardener, Quakertown, PA, USA) amended with 14 N-4.2 P-11.6 K controlled-release fertilizer (Osmocote; Scotts, Marysville, OH, USA) in the greenhouse. Whole uncut seeds were germinated as controls for each cultivar. Germination data was determined 15 days after planting (DAP). Four germination experiments were conducted, with 8 seeds for each treatment-cultivar combination. 


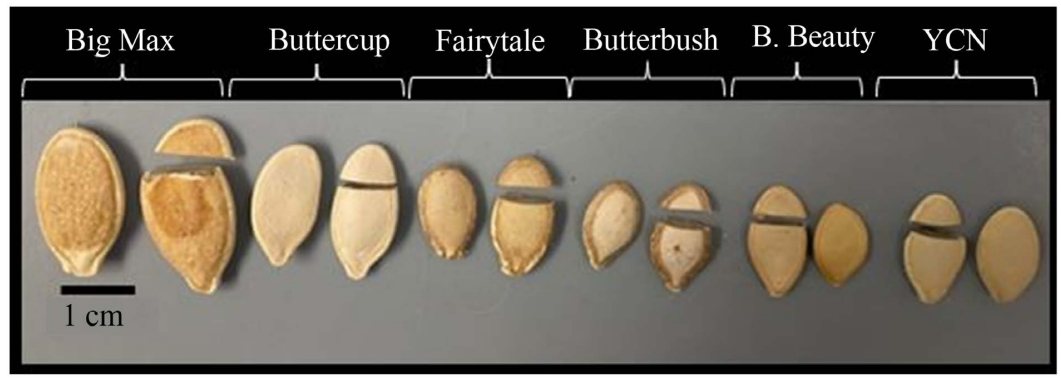

Figure 1. Whole and cut seeds of six squash cultivars belonging to Cucurbita maxima (Big Max and Buttercup), C. moschata (Fairytale and Butterbush) and C. pepo (Black Beauty and Yellow Crookneck).

Seed size for each cultivar was determined by average seed weight of ten seeds on a portable weighing balance (Ohaus Corporation, Parsippany, NJ), while the average seed length and seed width of twenty randomly chosen seeds was measured using a digital electronic caliper (Marathon, Richmond Hill ON, Canada). The average weight of seed tissue used for DNA extraction for each cultivar was determined by measuring the weight of ten seed chips.

\subsection{DNA Extraction}

Eight seed chips per cultivar were used for DNA extraction using four methods. The seed chips were placed in individual $2 \mathrm{ml}$ Eppendorf tubes with two 5- $\mathrm{mm}$ beads and immersed in liquid nitrogen for 4 minutes prior to grinding. The seed chips were then ground using a Harbil Paint Mixer (The Cary Company, IL, USA) for four minutes.

\subsubsection{CTAB Method}

Samples were incubated with $500 \mu \mathrm{l}$ of $3 \%$ cetyltrimethylammonium bromide (CTAB), $1 \%$ polyvinylpyrrolidone (PVP), and $0.2 \%(\mathrm{v} / \mathrm{v}) \beta$-mercaptoethanol in a water bath at $65^{\circ} \mathrm{C}$ for 30 minutes. The buffer also contained $100 \mathrm{mM}$ Tris-HCl, $1400 \mathrm{mM} \mathrm{NaCl}$, and $20 \mathrm{mM}$ EDTA. After incubation, $400 \mu \mathrm{l}$ of chloroform isoamyl (24:1) was added to each sample and centrifuged at 18,000 rpm for 15 minutes. A supernatant volume of $300-400 \mu \mathrm{l}$ was transferred into new tubes and incubated with $5 \mu \mathrm{RNAse}$ at $37^{\circ} \mathrm{C}$ for 15 minutes. A second wash with 400 $\mu \mathrm{l}$ of chloroform-isoamyl (24:1) was performed, and 300 - $400 \mu$ of the supernatant was transferred into new tubes. A $0.7 \times$ volume cold isopropanol was added to each sample. DNA was allowed to precipitate for $30 \mathrm{~min}$ at $-20^{\circ} \mathrm{C}$ and collected by centrifugation at $21,000 \mathrm{rpm}$ for 15 minutes. The pellets were washed twice with cold $70 \%$ ethanol and allowed to air dry before suspension in $50 \mu \mathrm{l}$ Tris-EDTA (10 mM Tris-HCl and $1 \mathrm{mM} \mathrm{EDTA}$ ).

\subsubsection{SDS Method}

Samples were incubated with $500 \mu \mathrm{l}$ of $2 \%$ sodium dodecyl sulfate (SDS), $1 \%$ $\mathrm{PVP}$, and $0.2 \% \beta$-Meracaptoethanol in a water bath at $65^{\circ} \mathrm{C}$ for 30 minutes. The buffer also contained $100 \mathrm{mM}$ Tris- $\mathrm{HCl}, 3000 \mathrm{mMNaCl}$, and $20 \mathrm{mM}$ EDTA. After incubation, $400 \mu \mathrm{l}$ of chloroform isoamyl (24:1) was added to each sample 
and centrifuged at $18,000 \mathrm{rpm}$ for 15 minutes. A supernatant volume of 300 $400 \mu \mathrm{l}$ was transferred into new tubes and incubated with $5 \mu \mathrm{l}$ RNAse at $37^{\circ} \mathrm{C}$ for 15 minutes. A second wash with $400 \mu \mathrm{l}$ of chloroform isoamyl (24:1) was performed, and $300-400 \mu \mathrm{l}$ of the supernatant was transferred into new tubes. A $0.7 \times$ volume cold isopropanol was added to each sample. DNA was allowed to precipitate for $30 \mathrm{~min}$ at $-20^{\circ} \mathrm{C}$ and collected by centrifugation at $21,000 \mathrm{rpm}$ for 15 minutes. The pellets were washed twice with cold $70 \%$ ethanol and allowed to air dry before suspension in $50 \mu \mathrm{l}$ Tris-EDTA $(10 \mathrm{mM}$ Tris- $\mathrm{HCl}$ and $1 \mathrm{mM}$ EDTA).

\subsubsection{Favorgen Method}

DNA extraction from the seed chips was carried out using the FavorPrep Plant DNA kit (Favorgen Biotech Corp, Ping-Tung, Taiwan) according to the manufacturer's instructions, with minor modifications. Briefly, samples were incubated with $500 \mu \mathrm{l}$ of the FAPG1 buffer and $8 \mu \mathrm{l}$ RNase in a water bath at $65^{\circ} \mathrm{C}$ for 30 minutes. The precipitate was treated with $130 \mu \mathrm{l}$ of the FAPG2 buffer and incubated in ice for 5 minutes. The sample was transferred to a Filter Column in a Collection tube and centrifuged at 18,000 rpm for 3 minutes. The clarified supernatant in Collection Tube was transferred to a new microcentrifuge tube and mixed with $1.5 \times$ volume of FAPG3 DNA-binding buffer by pipetting. An initial volume of $750 \mu \mathrm{l}$ from the mixture was applied to a FAPG DNA binding column in a collection tube and centrifuged at 18,000 rpm for 1 minute. The flow-through was discarded. This step was repeated for the remainder of the mixture. Exactly $500 \mu \mathrm{l}$ of W1 pre-wash buffer was added into the column and centrifuged for 30 seconds, and flow-through was discarded. The column was washed twice with $750 \mu \mathrm{l}$ of Wash Buffer and centrifuged for 30 seconds each. DNA in the column was allowed to dry by centrifuging at 18,000 rpm for 3 minutes. DNA was then obtained by placing the column in a microcentrifuge tube, adding $50 \mu$ Elution Buffer into the center of the column matrix, and centrifuging for 1 minute to obtain eluted DNA.

\subsubsection{EZNA Method}

DNA was extracted from the seed chips using the E.Z.N.A DNA extraction kit (Omega Biotek, Norcross, GA, USA) according to the manufacturer's instructions, with minor modifications as follows. Samples were incubated with $600 \mu \mathrm{l}$ P1 Buffer in a water bath at $65^{\circ} \mathrm{C}$ for 30 minutes. The precipitate was treated with $140 \mu \mathrm{P} 2$ buffer and centrifuged at 10,000 rpm for 10 minutes. Cleared lysate was transferred to a new microcentrifuge tube, mixed with $0.7 \times$ volume of $100 \%$ isopropanol, and immediately centrifuged at 14,000 rpm for 2 minutes. The supernatant was discarded, and the pellet was allowed to dry in a paper towel for 1 minute. $300 \mu \mathrm{l}$ sterile deionized water heated to $65^{\circ} \mathrm{C}$ was added to the pellet and samples were incubated at $65^{\circ} \mathrm{C}$ for 30 minutes. $4 \mu \mathrm{l}$ RNase A was added along with $150 \mu \mathrm{l}$ P3 Buffer and $300 \mu \mathrm{l} 100 \%$ ethanol and briefly vortexed gently. The entire sample was transferred into a HiBind ${ }^{\circledR}$ DNA Mini Column in a $2 \mathrm{~mL}$ Collection Tube and centrifuged at 10,000 rpm for 1 minute. Collection 
tube was discarded, and the column was transferred to a new collection tube. 650 $\mu \mathrm{l}$ of DNA Wash Buffer was then added to the column and centrifuged at 10,000 rpm for 1 minute. The filtrate was discarded, and the step was repeated. The column was allowed to dry by centrifuging at 10,000 rpm for 2 minutes and then placed in a new microcentrifuge tube. $50 \mu \mathrm{l}$ of Elution Buffer heated to $65^{\circ} \mathrm{C}$ was added and centrifuged for 1 minute to obtain eluted DNA.

The concentration and quality of the DNA for all the methods was determined by absorbance measurements (NanoDrop 8000; Thermo Fisher Scientific, Waltham, MA, USA) and agarose gel $(0.8 \% \mathrm{w} / \mathrm{v})$ electrophoresis.

\subsection{Genotyping with Molecular Markers}

\subsubsection{SSR Genotyping}

To determine utility for genotyping using microsatellite markers, the DNA extracted using the four methods was subjected to polymerase chain reaction (PCR) with an SSR primer marker (CMTP109) [10]. PCR was performed in a $15-\mathrm{mL}$ reaction containing $40 \mathrm{ng}$ of template DNA, $0.4 \mathrm{mM}$ each of forward primer (CAGAGCACCAGATCAGTGGA) and reverse primer

(GCAAAGCCTCCGCTCTATT), and PROMEGA Colorless GoTaq mastermix (Promega, Madison, WI). Amplification was performed on a SimpliAmp ${ }^{\text {tw }}$ Thermal Cycler (Applied Biosystems, Foster City, CA) using an initial 3 min denaturation at $95^{\circ} \mathrm{C}$, followed by 35 cycles of $15 \mathrm{~s}$ at $95^{\circ} \mathrm{C}, 20 \mathrm{~s}$ at $52^{\circ} \mathrm{C}$, and $30 \mathrm{~s}$ at $72^{\circ} \mathrm{C}$. The amplification was followed by a final extension step of $10 \mathrm{~min}$ at $72^{\circ} \mathrm{C}$. The PCR amplicons were run on an agarose gel ( $1 \% \mathrm{w} / \mathrm{v})$ electrophoresis.

\subsubsection{SNP Genotyping}

A Kompetitive allele specific PCR (KASP) assay was designed using BatchPrimer3 software (Albany, CA, USA) for a SNP marker (KASP-11) linked to a QTL for hull-less trait in Cucurbita. PCR assays were performed in $10 \mu \mathrm{l}$ reactions containing $5 \mu \mathrm{l}$ of $2 \times$ low ROX KASP master mix (LGC Genomics LLC., Teddington, UK), $0.16 \mu \mathrm{l}$ each of forward primers $(10 \mu \mathrm{M}), 0.41 \mu \mathrm{l}$ of reverse primer, $2 \mu \mathrm{l}$ of genomic DNA (50 ng/ $\mu \mathrm{l}$ ) and $2.27 \mu \mathrm{l}$ of $\mathrm{H}_{2} \mathrm{O}$. The PCR conditions consisted of an initial incubation at $94^{\circ} \mathrm{C}$ for $15 \mathrm{~min}$, a touchdown PCR at $94^{\circ} \mathrm{C}$ for $20 \mathrm{~s}, 61^{\circ} \mathrm{C}$ for $60 \mathrm{~s}$, with a $0.6^{\circ} \mathrm{C}$ decrease per cycle for 10 cycles, followed by 26 cycles of $94^{\circ} \mathrm{C}$ for $20 \mathrm{~s}$ and $55^{\circ} \mathrm{C}$ for $60 \mathrm{~s}$. Fluorescent end-point readings and cluster calling were performed using LightCycler ${ }^{\oplus} 480$ Instrument II (Roche Life Sciences, Penzberg, Upper Bavaria, Germany). KASP assays were only performed for DNA extraction methods that successfully amplified with the SSR marker (CMTp109).

\subsection{Statistical Analysis}

Data was analyzed using the PROC GLM procedure of SAS (SAS Institute Inc., Cary, NC) and means separation was done using Fisher's protected least significant difference test [23]. Pearson correlations between DNA concentration and seed-chip weight were calculated using JMP (Version 11; SAS Institute, Cary, 
NC).

\section{Results}

\subsection{Seed Size Traits and Germination}

Variation in seed size was observed across the six cultivars used in the current study. Seed length ranged from $10.88 \mathrm{~mm}$ to $18.89 \mathrm{~mm}$ (Table 1 ) and was significantly $(p<0.05)$ higher in Big Max cultivar (C. maxima) when compared to the other cultivars. This trend was consistent for all the seed size traits measured (Table 1 and Figure 1). The amount of seed tissue (seed chip) used for DNA extraction was also significantly higher for the Big Max cultivar and least in smallseeded cultivars, Yellow Crookneck and Butterbush.

Germination for whole and cut seeds ranged from $87.5 \%$ to $100 \%$ and $59.38 \%$ to $98.44 \%$, respectively. However, there was no significant difference in germination percentage between the whole and cut seeds within cultivars (Table 2 and Figure 2).

Table 1. Seed size traits of six squash cultivars representing Cucurbita pepo (Black beauty and yellow Crookneck), C. moschata (Fairytale and Butterbush) and C. maxima (Big Max and Buttercup).

\begin{tabular}{|c|c|c|c|c|}
\hline \multirow[b]{2}{*}{ Cultivar } & \multicolumn{4}{|c|}{ Seed size } \\
\hline & $\begin{array}{l}\text { Seed length } \\
(\mathrm{mm})\end{array}$ & $\begin{array}{l}\text { Seed width } \\
\quad(\mathrm{mm})\end{array}$ & $\begin{array}{c}10 \text { Seed } \\
\text { weight }(\mathrm{g})\end{array}$ & $\begin{array}{c}10 \text { Seed chip } \\
\text { weight (g) }\end{array}$ \\
\hline Black Beauty & $11.87^{c}$ & $7.05^{c}$ & $1.33^{\mathrm{c}}$ & $0.26^{\mathrm{bc}}$ \\
\hline Yellow Crookneck & $10.88^{\mathrm{d}}$ & $6.04^{\mathrm{d}}$ & $0.73^{\mathrm{d}}$ & $0.21^{\mathrm{c}}$ \\
\hline Butterbush & $10.59^{d}$ & $5.59^{d}$ & $0.76^{\mathrm{d}}$ & $0.17^{c}$ \\
\hline Fairytale & $14.24^{\mathrm{b}}$ & $7.61^{\mathrm{b}}$ & $1.50^{c}$ & $0.31^{\mathrm{bc}}$ \\
\hline Big Max & $18.89^{\mathrm{a}}$ & $11.33^{\mathrm{a}}$ & $2.91^{\mathrm{a}}$ & $0.59^{\mathrm{a}}$ \\
\hline Buttercup & $14.79^{\mathrm{b}}$ & $7.96^{\mathrm{b}}$ & $1.81^{\mathrm{b}}$ & $0.39^{\mathrm{b}}$ \\
\hline
\end{tabular}

Means within column followed by the same letter are not significantly different $(p<$ 0.05).

Table 2. Germination percentage of whole and cut seeds of six squash cultivars representing Cucurbita pepo (Black Beauty and Yellow Crookneck), C. moschata (Fairytale and Butterbush) and C. maxima (Big Max and Buttercup).

\begin{tabular}{ccc}
\hline \multirow{2}{*}{ Cultivars } & \multicolumn{2}{c}{ Germination (\%) } \\
\cline { 2 - 3 } & Whole seed & Cut seed \\
\hline Black Beauty & $87.50^{\mathrm{a}}$ & $68.75^{\mathrm{a}}$ \\
Yellow Crookneck & $100.00^{\mathrm{a}}$ & $98.44^{\mathrm{a}}$ \\
Butterbush & $96.87^{\mathrm{a}}$ & $87.50^{\mathrm{a}}$ \\
Fairytale & $93.75^{\mathrm{a}}$ & $75.00^{\mathrm{a}}$ \\
Big Max & $90.63^{\mathrm{a}}$ & $78.13^{\mathrm{a}}$ \\
Buttercup & $87.50^{\mathrm{a}}$ & $59.38^{\mathrm{a}}$ \\
\hline
\end{tabular}

Means within row followed by the same letter are not significantly different $(p<0.05)$. 


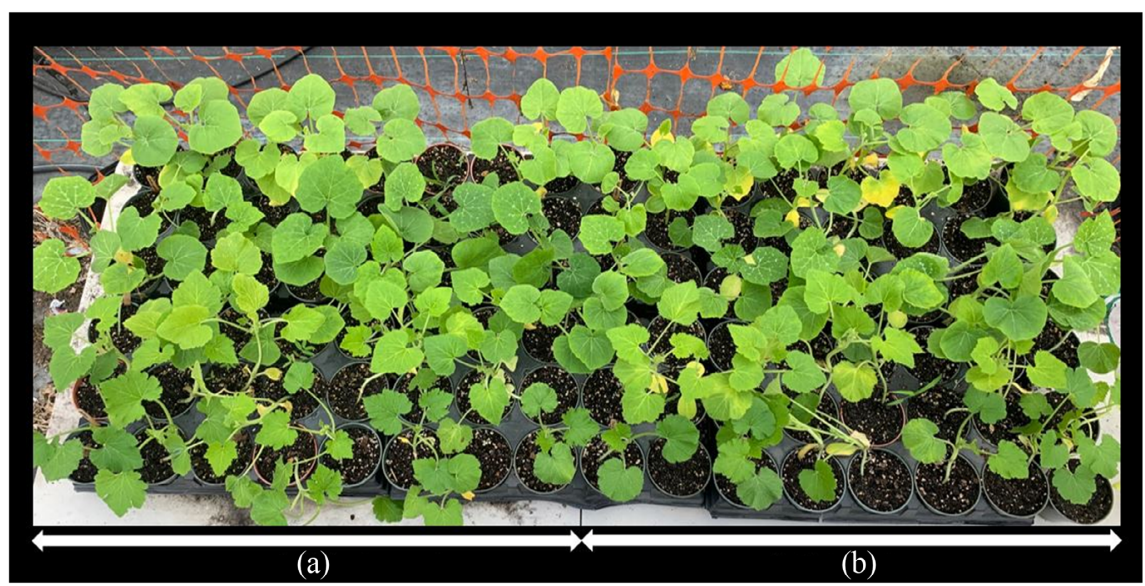

Figure 2. Seedling emergence for (a) whole seeds and (b) cut seeds at 15 days after planting for six squash cultivars belonging to Cucurbita maxima (Big Max and Buttercup), $C$. moschata (Fairytale and Butterbush) and C. pepo (Black Beauty and Yellow Crookneck).

\subsection{DNA Quantity and Quality}

DNA was obtained from all the cultivars, regardless of the extraction method used (Table 3 and Figure 3). The average DNA concentration ranged from 11.6 $\mathrm{ng} / \mu \mathrm{L}$ to $62.6 \mathrm{ng} / \mu \mathrm{L}$ and was significantly higher for $\mathrm{CTAB}$ method than the other methods. On the contrary, DNA quality for CTAB method was the lowest $\left(\mathrm{A}_{260 / 280}=0.89\right)$ among the methods tested. The two commercial kit methods (EZNA and Favorgen) yielded the highest quality DNA with values between 1.76 and 1.88. Gel electrophoresis revealed slight DNA degradation for samples extracted using EZNA and Favorgen methods, while minimal migration from the wells was observed for samples extracted using CTAB and SDS methods (Figure 3).

The DNA concentration across cultivars was low for the EZNA method and ranged from $4.8 \mathrm{ng} / \mu \mathrm{L}$ (Fairytale) to $16.3 \mathrm{ng} / \mu \mathrm{L}$ (Buttercup) (Table 4). On the other hand, the DNA quality $\left(\mathrm{A}_{260 / 280}\right)$ ranged from 1.57 (Fairytale) to 2.25 (Yellow Crookneck) for the EZNA method.

For the CTAB method, high DNA yields ranging from $23.2 \mathrm{ng} / \mu \mathrm{L}$ (Butterbush) to $126.2 \mathrm{ng} / \mu \mathrm{L}$ (Buttercup) were observed (Table 5). Conversely, this method recorded the lowest DNA quality $\left(\mathrm{A}_{260 / 280}\right)$ with values ranging from 0.77 (Big Max) to 1.01 (Butterbush).

The DNA concentration for the Favorgen method was modest and ranged from $10.7 \mathrm{ng} / \mu \mathrm{L}$ (Fairytale) to $31.1 \mathrm{ng} / \mu \mathrm{L}$ (Big Max) (Table 6). On the other hand, the DNA quality $\left(\mathrm{A}_{260 / 280}\right)$ ranged from 1.51 (Fairytale) to 2.17 (Butterbush) for this method.

The SDS method yielded DNA concentration between $7.9 \mathrm{ng} / \mu \mathrm{L}$ (Butterbush) and $22.0 \mathrm{ng} / \mu \mathrm{L}$ (Buttercup) (Table 7). The DNA quality $\left(\mathrm{A}_{260 / 280}\right)$ for the SDS method ranged from 1.48 (Big Max) to 2.58 (Butterbush).

Correlation between DNA concentration and seed-chip weight ranged between 0.43 and 0.79 but was not significant $(p<0.05)$ across the extraction methods $[(\mathrm{CTAB}=0.79),(\mathrm{SDS}=0.73),(\mathrm{EZNA}=0.45$ and $($ Favorgen $=0.43)]$. 


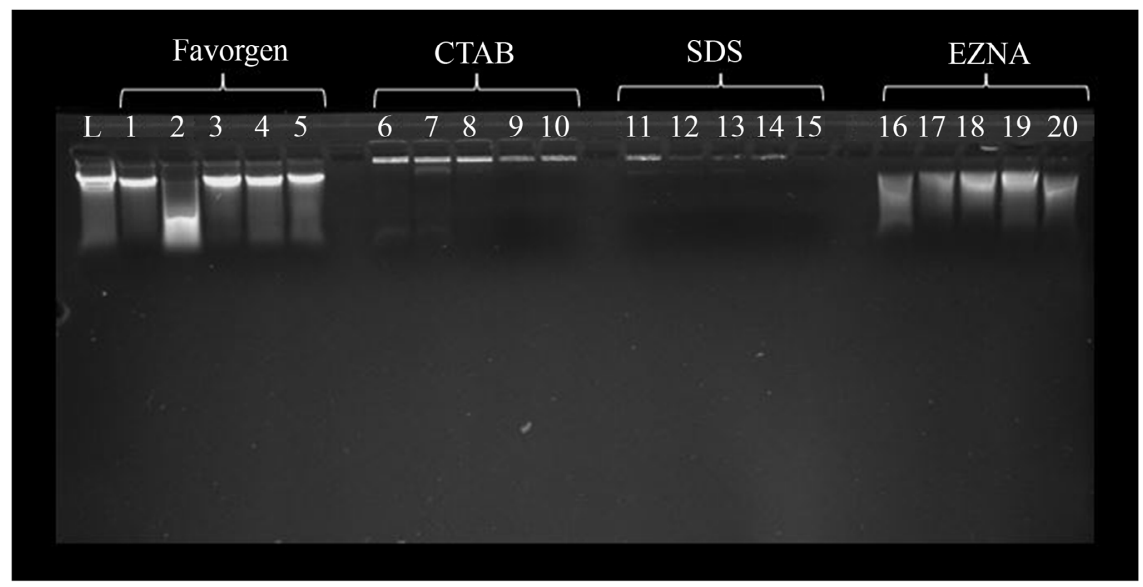

Figure 3. Quality of DNA samples extracted from six squash cultivars belonging to $\mathrm{Cu}$ curbita maxima (Big Max and Buttercup), C. moschata (Fairytale and Butterbush) and $C$. pepo (Black Beauty and Yellow Crookneck) using Favorgen (1 - 5), CTAB 6 - 10), SDS (11 - 15) and EZNA (16 - 20) extraction methods. L represents $\lambda$ DNA marker.

Table 3. Concentration (ng/ul) and quality $\left(\mathrm{A}_{260 / 280}\right)$ of DNA extracted from seeds of six squash cultivars representing Cucurbita pepo (Black Beauty and Yellow Crookneck), C. moschata (Fairytale and Butterbush) and C. maxima (Big Max and Buttercup) using CTAB, EZNA, Favorgen and SDS extraction methods.

\begin{tabular}{ccc}
\hline Method & DNA concentration $(\mathrm{ng} / \mu \mathrm{L})$ & DNA quality $\left(\mathrm{A}_{260 / 280}\right)$ \\
\hline CTAB & $62.62^{\mathrm{a}}$ & $0.89^{\mathrm{b}}$ \\
EZNA & $11.63^{\mathrm{b}}$ & $1.88^{\mathrm{a}}$ \\
Favorgen & $20.45^{\mathrm{b}}$ & $1.76^{\mathrm{a}}$ \\
SDS & $12.85^{\mathrm{b}}$ & $1.95^{\mathrm{a}}$ \\
\hline
\end{tabular}

Means within column followed by the same letter are not significantly different $(p<$ $0.05)$.

Table 4. Concentration (ng/ul) and quality $\left(\mathrm{A}_{260 / 280}\right)$ of DNA extracted from seeds of six squash cultivars representing Cucurbita pepo (Black Beauty and Yellow Crookneck), C. moschata (Fairytale and Butterbush) and C. maxima (Big Max and Buttercup) using EZNA kit extraction method.

\section{EZNA method}

\begin{tabular}{ccc}
\hline Cultivar & DNA concentration $(\mathrm{ng} / \mu \mathrm{l})$ & DNA quality $\left(\mathrm{A}_{260 / 280}\right)$ \\
\hline Black Beauty & $15.01^{\mathrm{ab}}$ & $2.11^{\mathrm{b}}$ \\
Yellow Crookneck & $9.216^{\mathrm{bc}}$ & $2.25^{\mathrm{a}}$ \\
Butterbush & $9.11^{\mathrm{bc}}$ & $1.77^{\mathrm{c}}$ \\
Fairytale & $4.76^{\mathrm{c}}$ & $1.57^{\mathrm{d}}$ \\
Big Max & $14.26^{\mathrm{ab}}$ & $1.82^{\mathrm{c}}$ \\
Buttercup & $16.29^{\mathrm{a}}$ & $2.11^{\mathrm{b}}$ \\
\hline
\end{tabular}

Means within column followed by the same letter are not significantly different $(p<$ 0.05). 
Table 5. Concentration (ng/ul) and quality $\left(\mathrm{A}_{260 / 280}\right)$ of DNA extracted from seeds of six squash cultivars representing Cucurbita pepo (Black Beauty and Yellow Crookneck), $C$. moschata (Fairytale and Butterbush) and C. maxima (Big Max and Buttercup) using CTAB extraction method.

\begin{tabular}{ccc}
\hline \multicolumn{3}{c}{ CTAB method } \\
\hline Cultivar & DNA concentration $(\mathrm{ng} / \mu \mathrm{l})$ & DNA quality $\left(\mathrm{A}_{260 / 280}\right)$ \\
\hline Black Beauty & $30.47^{\mathrm{bc}}$ & $0.87^{\mathrm{a}}$ \\
Yellow Crookneck & $24.24^{\mathrm{c}}$ & $0.91^{\mathrm{a}}$ \\
Butterbush & $23.23^{\mathrm{c}}$ & $1.01^{\mathrm{a}}$ \\
Fairytale & $103.52^{\mathrm{abc}}$ & $0.93^{\mathrm{a}}$ \\
Big Max & $112.54^{\mathrm{ab}}$ & $0.77^{\mathrm{a}}$ \\
Buttercup & $126.22^{\mathrm{a}}$ & $0.79^{\mathrm{a}}$
\end{tabular}

Means within column followed by the same letter are not significantly different $(p<$ 0.05).

Table 6. Concentration (ng/ul) and quality $\left(\mathrm{A}_{260 / 280}\right)$ of DNA extracted from seeds of six squash cultivars representing Cucurbita pepo (Black Beauty and Yellow Crookneck), $C$. moschata (Fairytale and Butterbush) and C. maxima (Big Max and Buttercup) using Favorgen kit extraction method.

\begin{tabular}{ccc}
\hline \multicolumn{3}{c}{ Favorgen method } \\
\hline Cultivar & DNA concentration $(\mathrm{ng} / \mu \mathrm{l})$ & DNA quality $\left(\mathrm{A}_{260 / 280}\right)$ \\
\hline Black Beauty & $24.76^{\mathrm{ab}}$ & $1.55^{\mathrm{bc}}$ \\
Yellow Crookneck & $26.23^{\mathrm{ab}}$ & $1.78^{\mathrm{b}}$ \\
Butterbush & $15.24^{\mathrm{ab}}$ & $2.17^{\mathrm{a}}$ \\
Fairytale & $10.66^{\mathrm{b}}$ & $1.51^{\mathrm{c}}$ \\
Big Max & $31.09^{\mathrm{a}}$ & $1.75^{\mathrm{bc}}$ \\
Buttercup & $16.89^{\mathrm{ab}}$ & $1.79^{\mathrm{b}}$
\end{tabular}

Means within column followed by the same letter are not significantly different $(p<$ $0.05)$.

Table 7. Concentration (ng/ul) and quality $\left(\mathrm{A}_{260 / 280}\right)$ of DNA extracted from seeds of six squash cultivars representing Cucurbita pepo (Black Beauty and Yellow Crookneck), $C$. moschata (Fairytale and Butterbush) and C. maxima (Big Max and Buttercup) using SDS extraction method.

\begin{tabular}{ccc}
\hline \multicolumn{3}{c}{ SDS method } \\
\hline Cultivar & DNA concentration $(\mathrm{ng} / \mu \mathrm{l})$ & DNA quality $\left(\mathrm{A}_{260 / 280}\right)$ \\
\hline Black Beauty & $8.47^{\mathrm{c}}$ & $1.99^{\mathrm{ab}}$ \\
Yellow Crookneck & $10.32^{\mathrm{bc}}$ & $1.83^{\mathrm{ab}}$ \\
\hline
\end{tabular}


Continued

\begin{tabular}{ccc}
\hline Butterbush & $7.89^{\mathrm{c}}$ & $2.58^{\mathrm{a}}$ \\
Fairytale & $10.46^{\mathrm{bc}}$ & $2.12^{\mathrm{ab}}$ \\
Big Max & $17.35^{\mathrm{ab}}$ & $1.48^{\mathrm{b}}$ \\
Buttercup & $22.03^{\mathrm{a}}$ & $1.83^{\mathrm{ab}}$ \\
\hline
\end{tabular}

Means within column followed by the same letter are not significantly different $(p<$ $0.05)$.

Consistent amplification with SSR marker CMTp109 was obtained only for DNA derived from the EZNA and Favorgen methods (Figure 4).

Further genotyping with SNP marker $(K A S P-11)$ for DNA derived from EZNA and Favorgen methods was also successful (Figure 5). As expected, all the DNA samples contained the allele for hulled genotype, while the control DNA sample contained the allele for hull-less genotype.

\section{Discussion}

Implementing a seed-based genotyping system for squash requires a non-destructive sampling method that allows reliable germination, while the resulting DNA must be of sufficient quantity and quality for downstream applications [16]. In the current study, six cultivars of squash representing the major species of squash ( $C$. pepo, C. moschata and C. maxima) and varying seed characteristics were used to develop a suitable seed-based genotyping system for the crop. The average seed size (seed length) across cultivars was $13.54 \mathrm{~mm}$ but ranged from $10.59 \mathrm{~mm}$ (Butterbush) to $18.89 \mathrm{~mm}$ (Big Max). Despite the vast differences in seed size among the cultivars, sampling $1 / 3$ of the seed for DNA extraction did not significantly affect germination percentage for the remnant seed-embryo. Seed-size is an important consideration for a non-destructive sampling system, particularly for cultivars with small seeds. For example, in watermelon [21] and maize [16], sampling of larger portion of seeds for DNA extraction significantly affected germination percentage of remnant seed-embryo due to depleted energy reserves.

DNA yield across the four methods ranged from $0.5 \mu \mathrm{g}$ (EZNA) to $3.13 \mu \mathrm{g}$ $(\mathrm{CTAB})$ and is of sufficient quantity for application in marker-assisted selection. The correlation $(0.43$ - 0.79) between DNA concentration and seed chip size was moderate to high but not significant, suggesting that the efficiency of DNA extraction across methods was independent of the amount of seed tissue. PCR with an SSR marker (CMTP109) was performed to determine the usefulness of the extracted DNA for marker-assisted selection. DNA extracted using the CTAB and SDS methods did not consistently amplify with SSR marker CMTp109, suggesting presence of PCR inhibiting contaminants such as proteins, polysaccharides, and polyphenols [16] [24]. On the contrary, DNA obtained using EZNA and Favorgen methods amplified successfully with SSR and SNP markers. 


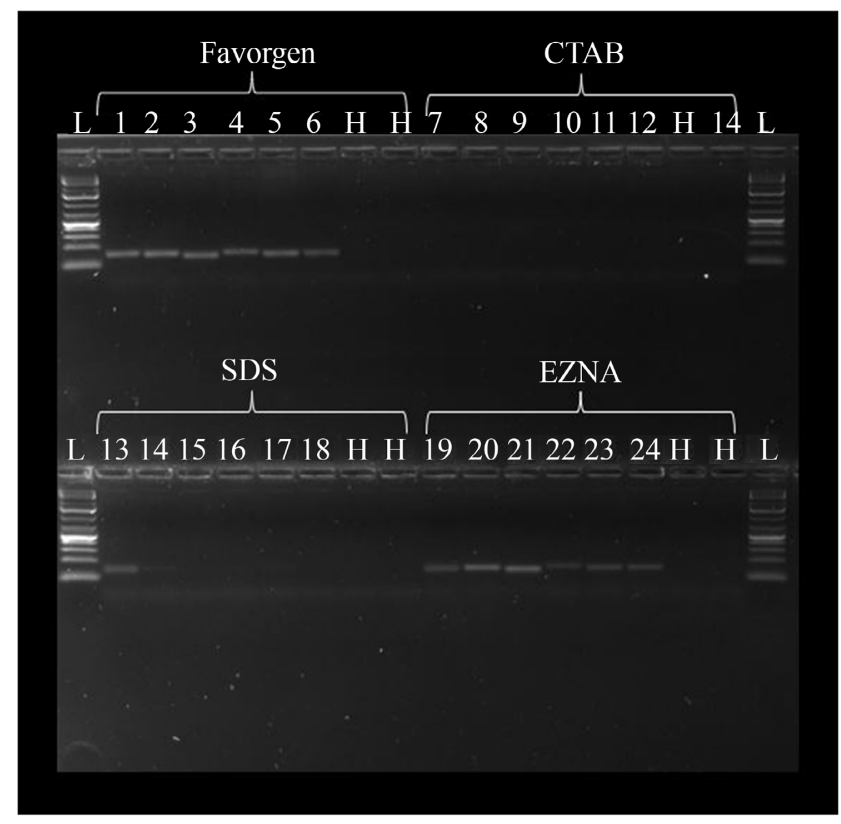

Figure 4. PCR amplification (SSR) of DNA extracted from six squash cultivars belonging to Cucurbita maxima (Big Max and Buttercup), C. moschata (Fairytale and Butterbush) and C. pepo (Black Beauty and Yellow Crookneck) using Favorgen (1 - 6), CTAB (7 - 12), SDS (13 - 18) and EZNA (19 - 24) extraction methods. H and L represent water and 100 bp DNA ladder, respectively.

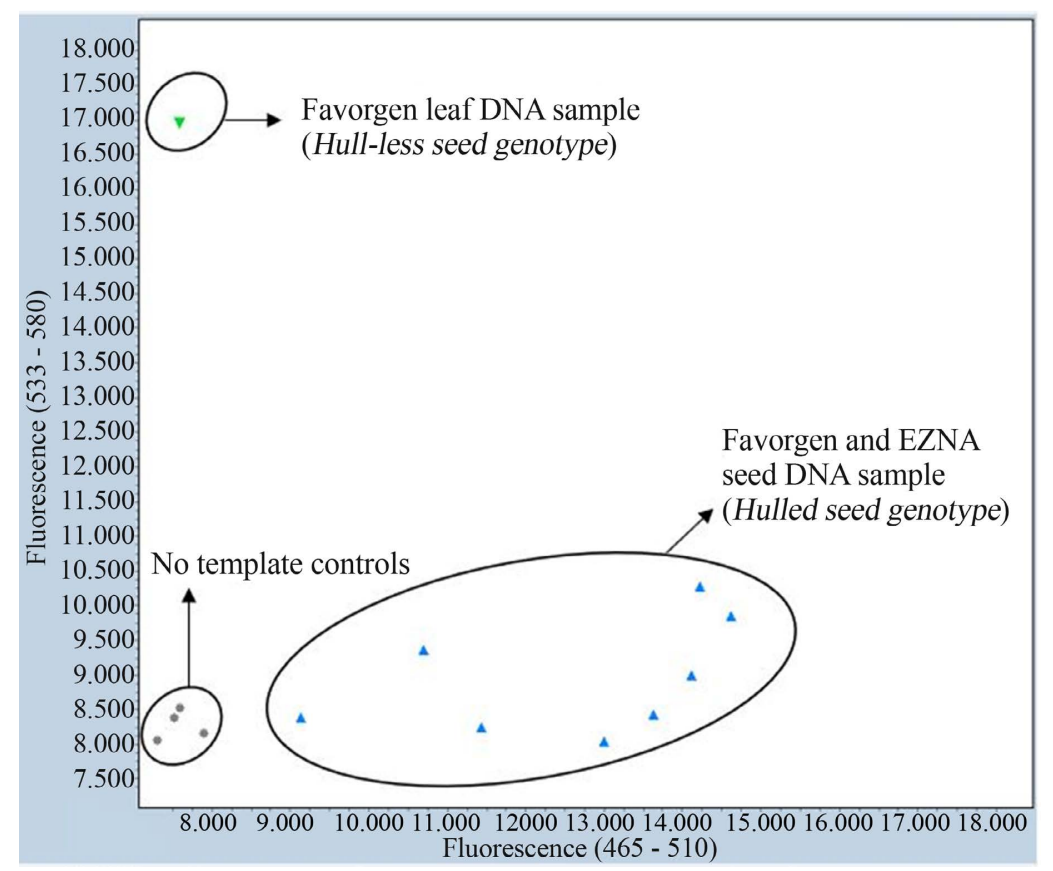

Figure 5. A KASP assay with a SNP marker targeting hull-less seed trait in Cucurbita using DNA extracted from six squash cultivars belonging to Cucurbita maxima (Big Max and Buttercup), C. moschata (Fairytale and Butterbush) and C. pepo (Black Beauty and Yellow Crookneck) using Favorgen and EZNA extraction methods. The green triangle represents the allele for hull-less seed genotype in a leaf DNA sample of control cultivar Kakai ( $C$. pepo), blue triangles represent the allele for hulled seed genotype in the six cultivars and the gray circles represent no template controls. 


\section{Conclusion}

In the current study, a non-destructive seed-based genotyping system for marker-assisted selection in squash was developed. Although DNA could be obtained using all the extraction methods, only EZNA and Favorgen methods yielded DNA of sufficient quality for marker-assisted selection. Additional research is required to improve the yield of DNA for the two methods.

\section{Conflicts of Interest}

The authors declare no conflicts of interest regarding the publication of this paper.

\section{Funding}

This research was partially funded by the USDA NIFA REEU Program (\#GRANT12124888).

\section{References}

[1] Paris, H.S. (1989) Historical Records, Origins, and Development of the Edible Cultivar Groups of Cucurbita pepo (Cucurbitaceae). Economic Botany, 43, 423-443. https://doi.org/10.1007/BF02935916

[2] Robinson, R. and Decker-Walters, D. (1997) Cucurbits. Centre for Agriculture and Bioscience International, Wallingford.

[3] Teppner, H. (2000) Cucurbita pepo (Cucurbitaceae)-History, Seed Coat Types, Thin Coated Seeds and Their Genetics. Phyton (Horn), 40, 1-42.

[4] Paris, H.S. (2016) Germplasm Enhancement of Cucurbita pepo (Pumpkin, Squash, Gourd: Cucurbitaceae): Progress and Challenges. Euphytica, 208, 415-438. https://doi.org/10.1007/s10681-015-1605-y

[5] Shrestha, S., Michael, V.N., Fu, Y. and Meru, G. (2021) Genetic Loci Associated with Resistance to Zucchini Yellow Mosaic Virus in Squash. Plants, 10, Article No. 1935. https://doi.org/10.3390/plants10091935

[6] Tuberosa, R., Salvi, S., Sanguineti, M.C., Maccaferri, M., Giuliani, S. and Landi, P. (2003) Searching for Quantitative Trait Loci Controlling Root Traits in Maize: A Critical Appraisal. Plant and Soil, 255, 35-54. https://doi.org/10.1023/A:1026146615248

[7] Montero-Pau, J., Blanca, J., Bombarely, A., Ziarsolo, P., Esteras, C., Martí-Gómez, C., Ferriol, M., Gómez, P., Jamilena, M., Mueller, L., et al. (2018) De Novo Assembly of the Zucchini Genome Reveals a Whole-Genome Duplication Associated with the Origin of the Cucurbita Genus. Plant Biotechnology Journal J, 16, 1161-1171. https://doi.org/10.1111/pbi.12860

[8] Sun, H., Wu, S., Zhang, G., Jiao, C., Guo, S. and Ren, Y. (2017) Karyotype Stability and Unbiased Fractionation in the Paleo-Allotetraploid Cucurbita Genomes. Molecular Plant, 10, 1293-1306. https://doi.org/10.1016/j.molp.2017.09.003

[9] Esteras, C., Gomez, P., Monforte, A.J., Blanca, J., Vicente-Dolera, N., Roig, C., Nuez, F. and Pico, B. (2012) High-Throughput SNP Genotyping in Cucurbita pepo for Map Construction and Quantitative Trait Loci Mapping. BMC Genomics, 13, Article No. 80. https://doi.org/10.1186/1471-2164-13-80 
[10] Gong, L., Stift, G., Kofler, R., Pachner, M. and Lelley, T. (2008) Microsatellites for the Genus Cucurbita and an SSR-Based Genetic Linkage Map of Cucurbita pepo L. Theoretical and Applied Genetics, 117, 37-48. https://doi.org/10.1007/s00122-008-0750-2

[11] Blanca, J., Cañizares, J., Roig, C., Ziarsolo, P., Nuez, F. and Picó, B. (2011) Transcriptome Characterization and High Throughput SSRs and SNPs Discovery in Cucurbita pepo (Cucurbitaceae). BMC Genomics, 12, Article No. 104. https://doi.org/10.1186/1471-2164-12-104

[12] Brown, R.N. and Myers, J.R. (2002) A Genetic Map of Squash (Cucurbita sp.) with Randomly Amplified Polymorphic DNA Markers and Morphological Markers. Journal of the American Society for Horticultural Science, 127, 568-575.

https://doi.org/10.21273/JASHS.127.4.568

[13] Ramos, A., Fu, Y., Michael, V. and Meru, G. (2020) QTL-Seq for Identification of Loci Associated with Resistance to Phytophthora Crown Rot in Squash. Scientific Reports, 10, Article No. 5326. https://doi.org/10.1038/s41598-020-62228-Z

[14] Vogel, G., LaPlant, K.E., Mazourek, M., Gore, M.A. and Smart, C.D. (2021) A Combined BSA-Seq and Linkage Mapping Approach Identifies Genomic Regions Associated with Phytophthora Root and Crown Rot Resistance in Squash. Theoretical and Applied Genetics, 134, 1015-1031. https://doi.org/10.1007/s00122-020-03747-1

[15] Zraidi, A., Stift, G., Pachner, M., Shojaeiyan, A., Gong, L. and Lelley, T. (2007) A Consensus Map for Cucurbita pepo. Molecular Breeding, 20, 375-388. https://doi.org/10.1007/s11032-007-9098-6

[16] Gao, S., Martinez, C., Skinner, D., Krivanek, A., Crouch, J. and Xu Y. (2008) Development of a Seed DNA-Based Genotyping System for Marker-Assisted Selection in Maize. Molecular Breeding, 22, Article No. 477.

https://doi.org/10.1007/s11032-008-9192-4

[17] Kang, H.W., Cho, Y.G., Yoon, U. and Eun, M.Y. (1998) A Rapid DNA Extraction Method for RFLP and PCR Analysis from a Single Dry Seed. Plant Molecular Biology Reporter, 16, Article No. 90. https://doi.org/10.1023/A:1007418606098

[18] Marsal, G., Boronat, N., Canals, J., Zamora, F. and Fort, F. (2013) Comparison of the effiCiency of Some of The Most Usual DNA Extraction Methods for Woody Plants in Different Tissues of Vitis vinifera L. Journal international des sciences de la vigne et $d u$ vin, 47, 227-237. https://doi.org/10.20870/oeno-one.2013.47.4.1559

[19] von Post, R., von Post, L., Dayteg, C., Nilsson, M., Forster, B.P. and Tuvesson, S. (2003) A High-Throughput DNA Extraction Method for Barley Seed. Euphytica, 130, 255-260. https://doi.org/10.1023/A:1022863006134

[20] Abd-Elsalam, K., Bahkali, A., Moslem, M., Amin, O.E. and Niessen, L. (2011) An Optimized Protocol for DNA Extraction from Wheat Seeds and Loop-Mediated Isothermal Amplification (LAMP) to Detect Fusarium graminearum Contamination of Wheat Grain. International Journal of Molecular Sciences, 12, 3459-3472. https://doi.org/10.3390/ijms12063459

[21] Meru, G., McDowell, D., Waters, V., Seibel, A., Davis, J. and McGregor, C. (2013) A Non-Destructive Genotyping System from a Single Seed for Marker-Assisted Selection in Watermelon. Genetics and Molecular Research, 12, 702-709. https://doi.org/10.4238/2013.March.11.18

[22] Kamiya, M. and Kiguchi, T. (2003) Rapid DNA Extraction Method from Soybean Seeds. Breeding Science, 53, 277-279. https://doi.org/10.1270/jsbbs.53.277

[23] Ott, R.L. and Longnecker, M. (2001) An Introduction to Statistical Methods and 
Data Analysis. 5th Edition, Duxbury Press, Pacific Grove.

[24] Thermo-Scientific (2008) Nanodrop 1000 Spectrophotometre V3.7 User's Manual. Thermo Fisher Scientific Inc., Wilmington. 